Dicle Tıp Dergisi / Dicle Med J (2019) 46 (1) : 65 - 72

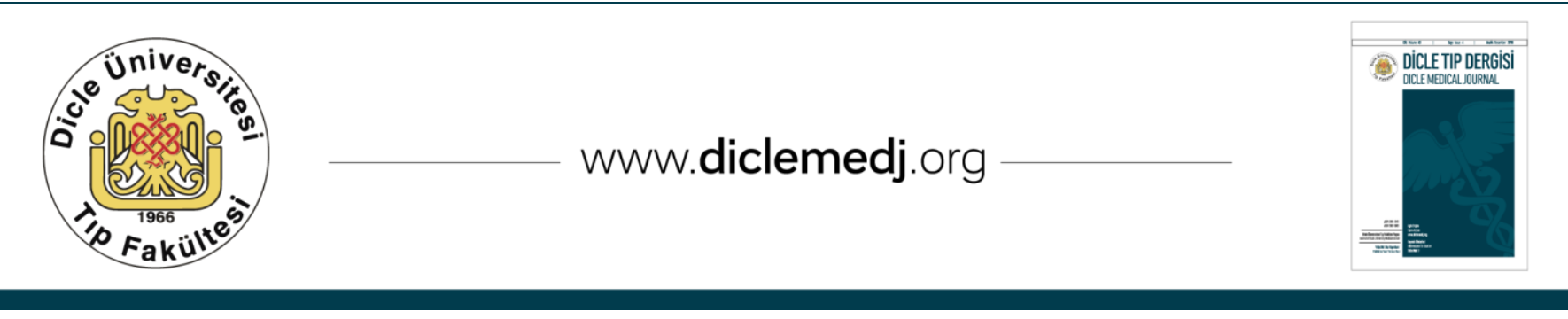

Original Article / Özgün Araştırma

\title{
Ciprofloxacin is not a better choice in the patients with diabetes suffering urinary tract infection
}

\author{
Kader Ugur1, Isa Ahmet Bal², Ayse Sagmak Tartar ${ }^{3}$, Nevzat Gozel ${ }^{4}$, Bedrettin Orhan5, \\ Emir Donder6, Abdullah Mubin Ozercan ${ }^{7}$
}

1 Endocrinology and Metabolic Diseases, School of Medicine, Firat University, Elazig, Turkey ORCID: 0000-0003-4038-2041

2 Department of Infectious Diseases and Clinical Microbiology, School of Medicine, Firat University, Elazig, Turkey ORCID: 0000-0002-0893-8218

3 Department of Infectious Diseases and Clinical Microbiology, School of Medicine, Firat University, Elazig, Turkey 0RCID: 0000-0002-9052-7986

4 Internal Medicine, School of Medicine, Firat University, Elazig, Turkey ORCID: 0000-0001-7326-6860

5 Public Health Department of Bursa, Bursa, Turkey ORCID: 0000-0003-3970-2344

6 Internal Medicine, School of Medicine, Firat University, Elazig, Turkey ORCID:0000-0003-2537-6023

7 Gastroenterology, School of Medicine, Firat University, Elazig, Turkey ORCID: 0000-0002-6968-7838

Received: 09.09.2018; Revised: 17.10.2018; Accepted: 25.10.2018

\begin{abstract}
Objective: The aim of this study is to determine antibacterial susceptibilities of Gram-negative bacteria isolated from diabetic and non-diabetic patients as infectious agents of community-acquired urinary tract infections (UTI) and to compare their rates of resistance to the antibiotics frequently used in empirical treatment.

Methods: Ninety-six diabetic and sixty-eight non-diabetic (total $n=164$ ) patients' data were evaluated retrospectively who diagnosed as community-acquired urinary system infection and consulted to outpatient clinics of Department of Endocrinology and Infectious Diseases of Firat University School of Medicine between January 1st, 2014 and December 31st, 2014 whose urine cultures demonstrated Gram-negative bacteria were included in the study. Antibiotic susceptibilities of the isolated bacteria were determined using Vitek 2 automated system and the results were evaluated as sensitive and resistant.

Results: In both diabetic and non-diabetic patient groups, most frequently Escherichia coli $(88.5 \%$ in diabetic and $85.3 \%$ in non-diabetic groups) were isolated. In the diabetic group, microorganisms mostly demonstrated the highest rates of resistance against ampicillin, cephalosporins, ciprofloxacin, amoxicillin-clavulanic acid and in the non-diabetic group ampicillin, amoxicillin-clavulanic acid, cefuroxime and trimethoprim-sulfamethoxazole.

Conclusion: Resistance to ciprofloxacin was at a significantly higher rate in the diabetic group. In diabetic patients, it will be more appropriate to give antibiotherapy in urinary system infections based on the antibacterial susceptibility test results.
\end{abstract}

Keywords: Diabetes mellitus, urinary tract infection, antibiotic susceptibility.

\section{DOI: 10.5798/dicletip.474694}

Yazışma Adresi / Correspondence: Kader Uğur, Endocrinology and Metabolic Diseases, School of Medicine, Firat University, Elazig, Turkey e-mail: kaderaksoy06@hotmail.com 


\section{İdrar Yolu Enfeksiyonu Geçiren Diyabetli Hastalarda Siprofloksasin İyi Bir Seçenek Değildir}

$\ddot{0} \mathbf{z}$

Amaç: Bu çalışmanın amacı diyabetik ve diyabeti olmayan bireylerden izole edilen Gram-negatif bakterilerin toplum kaynaklı idrar yolu enfeksiyonlarının enfeksiyöz ajanları olarak antibakteriyel duyarlılıklarını saptamak ve ampirik tedavide sıklıkla kullanılan antibiyotiklere direnç oranlarını karşılaştırmaktır.

Yöntemler: 1 Ocak- 31 Aralık 2014 tarihleri arasında Fırat Üniversitesi Endokrinoloji ve Enfeksiyon Hastalıkları kliniklerine başvuran toplum kaynaklı idrar yolu enfeksiyonu tanısı almış ve idrar kültürlerinde gram negatif bakteri üremesi olan 96 diyabetik ve 68 diyabetik olmayan hastanın dosyaları retrospektif olarak incelendi. İzole edilen bakterilerin antibiyotik duyarlılıkları, Vitek 2 otomatik sistem kullanılarak belirlenmiști ve sonuçlar duyarlı ve dirençli olarak değerlendirildi.

Bulgular: Hem diyabetik hem de diyabetik olmayan hasta gruplarında en sık Escherichia coli (diyabetiklerde \%88,5 ve diyabetik olmayan grupta \%85,3) izole edildi. Diyabetik grupta mikroorganizmalar, ampisiline, sefalosporinlere, siprofloksasine, amoksisilin-klavulanik aside ve diyabetik olmayan grup ampisilin, amoksisilin-klavulanik asit, sefuroksim ve trimetoprim-sülfametoksazole karşı en yüksek direnç oranlarını göstermiştir.

Sonuç: Diyabetik grupta Siprofloksasin direnci anlamlı olarak daha yüksekti. Üriner sistem enfeksiyonları olan diyabetik hastalarda, antibiyotik verileceği zaman antibakteriyel duyarlılık testi sonuçlarına dayanarak verilmesi daha uygun olacaktır.

Anahtar kelimeler: Diabetes mellitus, idrar yolu enfeksiyonu, antibiyotik duyarlılığı.

\section{INTRODUCTION}

Diabetes mellitus is a metabolic disease characterized by insulin deficiency and ineffectiveness or both. Besides diabetes is a chronic disease increasing in frequency with acute and chronic complications, which also causes serious workforce loss, incurs heavy economic burden and increased morbidity and mortality. In the year 2014, 387 million diabetic patients were living in the world and this number is predicted to rise to 593 million in the year $2035^{1}$.

In diabetic patients, frequently complicated urinary system diseases are detected. In diabetic patients, symptomatic bacteriuria leads a more severe course. Therefore, accurate diagnosis and appropriate treatment are important $^{2}$. In diabetic patients, the frequency of UTI is higher than that in the general population. UTI develops more frequently in female, rather than male diabetic patients. Every year, an average of $8.2 \%$ diabetic patients receive the diagnosis of UTI (in women, $12.9 \%$ and men, $3.9 \%)^{3}$.
Increased prevalence of bacteriuria and symptomatic UTI in diabetic patients can stem from the difference between diabetic and nondiabetic patients regarding host response and infective characteristics of the bacteria ${ }^{2}$. Higher glucose concentration in urine may contribute to the development of pathogenic bacteria 4 . In urinary infections seen in diabetic patients the pathogenic agents are mostly Escherichia coli and other members of the Enterobacteriaceae species $^{5}$.

In the whole world, in line with the increase in the incidence of type 2 diabetes mellitus, the number of diagnosis of UTI made in these patients also increased which caused a significant increase in health care expenses ${ }^{3}$. Besides in these patients prescription of broad spectrum antibiotics can trigger the development of antibiotic resistant pathogens ${ }^{6}$. In urinary system infections as empirical treatment quinolone group of antibiotics are used $^{7}$. Recently, in our patients whom we followed up in our clinic UTIs caused by resistant pathogens are seen. 
The purpose of this study is to determine antibacterial susceptibilities of Gram-negative bacteria isolated from urine cultures of diabetic and non-diabetic patients, which are pathogens of community-acquired urinary system infections, and to compare especially bacterial resistances to antibiotics frequently used in empirical treatment.

Ninety-six diabetic and sixty-eight non-diabetic (total $n=164$ ) patients' data were assessed retrospectively who diagnosed as communityacquired urinary system infection and consulted to outpatient clinics of Department of Endocrinology and Infectious Diseases of Firat University School of Medicine between January 1st, 2014 and December 31st, 2014 whose urine cultures demonstrated Gram-negative bacteria were included in the study. Patients who met 2015 diagnostic criteria8 for diabetes mellitus (DM) set by American Association of Diabetes which are used in routine practice for diagnosis and classification of DM, were enrolled in the study. Result of one urine culture of each patient was evaluated. Patients with nosocomial infections, indwelling urinary catheters and those aged less than 18 years were not included in the study. The protocol of this study was approved by the Ethics Committee of Firat University (meeting 14, issue, 3, dated 06.09.2018). Antibiotic susceptibilities of the isolated bacteria were again determined using Vitek 2 automated system and the results were evaluated as sensitive and resistant.

For the statistical analysis of data SPSS 21.0 package program was used. Parametric data were expressed as means \pm standard deviation and categorical data as percentages. For intergroup comparisons categorical data were analyzed using chi-square test and Fisher's exact chi-square test, while for parametric data Student's T test was used. For all statistical evaluations $p<0.05$ was accepted as the level of significance.

\section{RESULTS}

96 diabetic and 68 non-diabetic patients (total $\mathrm{n}=164$ ) were included in the study. Demographic data of the patients are presented in Table 1. In both diabetic and non-diabetic patient groups, most frequently Escherichia coli (88.5\% in diabetic and $85.3 \%$ in non-diabetic groups) and Klebsiella pneumoniae $(9.4 \%$ and $11.8 \%$, respectively) were isolated. Extended spectrum beta-lactamase (ESBL) produced by pathogenic microorganisms were observed in $20.8 \%$ and $13.2 \%$ of the patients in the diabetic and non-diabetic groups, respectively. Distribution of the isolated gram-negative bacteria is given in Table 2 .

Table 1: Demographic characteristics of diabetic and non-diabetic patients

\begin{tabular}{|c|c|c|}
\hline Gender & Diabetic $\mathrm{n}(\%)$ & Non-diabetic $\mathrm{n}(\%)$ \\
\hline Female & $90(93.7)$ & $63(92.6)$ \\
Male & $6(6.3)$ & $5(7.4)$ \\
Total & $96(100)$ & $68(100)$ \\
\hline Average age & $61.6 \pm 12.6$ & $42.5 \pm 15.1$ \\
Age Range & $29-87$ & $19-75$ \\
\hline
\end{tabular}

Table 2: Distribution of isolated Gram-negative bacteria

\begin{tabular}{|l|c|c|}
\hline Microorganisms & $\begin{array}{c}\text { Diabetic group } \\
\mathbf{n}(\boldsymbol{\%})\end{array}$ & $\begin{array}{c}\text { Non- diabetic group } \\
\mathbf{n}(\boldsymbol{\%})\end{array}$ \\
\hline E. coli & $85(88.5)$ & $58(85.3)$ \\
K. pneumoniae & $9(9.4)$ & $8(11.8)$ \\
Other & $2 *(2.1)$ & $2 * *(2.9)$ \\
Total & $96(100)$ & $68(100)$ \\
\hline
\end{tabular}

*Pseudomonas aeruginosa and Enterobacter aerogenes **P. aeruginosa and Proteus mirabilis

According to antibacterial susceptibilities of isolated microorganisms, the most effective antibiotics in both groups were carbapenems, nitrofurantoin, amikacin and piperacillintazobactam. In the diabetic group, microorganisms mostly demonstrated the highest rates of resistance against ampicillin, cephalosporins, ciprofloxacin, and amoxicillinclavulanic acid and in the non-diabetic group ampicillin, amoxicillin-clavulanic acid, 
cefuroxime and trimethoprimsulfamethoxazole in the decreasing order of frequency. Antibacterial susceptibilities of Gram-negative bacteria are shown in Table 3.

Accordingly, in the diabetic group bacterial resistance against ciprofloxacin was greater in the diabetic group $(\mathrm{p}<0.01)$. In the diabetic group $\chi 2$ value for ciprofloxacin was 9.88 . For other antibiotics significant intergroup difference was not detected (for each antibiotic $\mathrm{p}>0.05$ ).

\section{DISCUSSION}

Community-acquired UTI is the most prevalent bacterial infection in the world 9 . For the treatment of these infections, usually empirical treatment is applied which contributes to the development of resistance. Increase in the resistance against antibiotics frequently used in urinary system infections complicates therapeutic procedures and new treatment alternatives are brought into agenda ${ }^{10}$. As is already known, immune system of diabetic patients is compromised and their risks of contracting various infections are also enhanced $^{11}$. When compared with nondiabetics, incidence of symptomatic UTI is higher and more frequently results in complications in diabetics. These infections are generally regarded as complicated infections. Glycemic regulation, pregnancy, urinary system anomalies, life style factors as sexual activity and other comorbidities potentially effects development of UTIs 2. Diabetic patients carry a higher risk of contracting infections and especially urinary system infections ${ }^{12}$. Higher incidence of UTIs in diabetics can be explained by decrease in neutrophil response, lower levels of urinary cytokines and leukocyte concentrations which facilitate adhesion of microorganisms to uroepithelial cells ${ }^{13}$.
Table 3: Antibacterial susceptibilities of Gram-negative bacteria isolated from the urine cultures of diabetic and non-diabetic patients

\begin{tabular}{|l|c|c|}
\hline Antibiotics & $\begin{array}{c}\text { Diabetic (n=96) } \\
\mathbf{n}(\boldsymbol{\%})\end{array}$ & $\begin{array}{c}\text { Non-diabetic (n=68) } \\
\mathbf{n}(\mathbf{\%})\end{array}$ \\
\hline Ampicillin & $26(27.1)$ & $35(51.4)$ \\
\hline Ampicillin-sulbactam & $63(65.6)$ & $52(76.4)$ \\
\hline Amoxicillin-clavulanic acid & $54(56.2)$ & $40(58.8)$ \\
\hline Cefuroxime & $38(39.6)$ & $42(61.7)$ \\
\hline Ceftriaxone & $38(39.6)$ & $45(66.1)$ \\
\hline Ceftazidime & $40(41.6)$ & $46(67.6)$ \\
\hline Cefepime & $50(52.1)$ & $50(73.5)$ \\
\hline Gentamicin & $87(88.8)$ & $61(89.7)$ \\
\hline Amikacin & $90(93.7)$ & $68(100)$ \\
\hline Ciprofloxacin* & $53(55.2)$ & $55(80.8)$ \\
\hline $\begin{array}{l}\text { Trimethoprim- } \\
\text { sulfamethoxazole }\end{array}$ & $62(64.5)$ & $44(64.7)$ \\
\hline Nitrofurantoin & $93(96.8)$ & $68(100)$ \\
\hline Piperacillin-tazobactam & $86(89.5)$ & $64(94.1)$ \\
\hline Ertapenem & $96(100)$ & $68(100)$ \\
\hline Imipenem & $96(100)$ & $68(100)$ \\
\hline Meropenem & $96(100)$ & $68(100)$ \\
\hline
\end{tabular}

In our study, as is the case with other studies we found higher incidence of UTI in women relative to men. Treatment of urinary system infection changes dependent on the patient's age, gender, underlying disease, infectious agent and upper or lower urinary tract involvement. Female gender has been considered to be an independent risk factor for the development of urinary system infection in a diabetic individual ${ }^{14,15}$. In previous studies advanced age, duration of diabetes and control level of the disease has been described as risk factors. Similarly, body mass index, history of UTI and sexual intercourse has been defined as independent risk factors among diabetics ${ }^{16}$.

In our study, most frequently E. coli was isolated. This result is in compliance with other studies. Based on literature studies in $90 \%$ of urinary system infections in diabetic patients pathogenic agent is E. coli ${ }^{17}$. Antibiotic resistance of uropathogens involving in community-acquired and nosocomial urinary 
system infections is gradually increasing 18,19 . The increase in bacterial resistance rates may be due to the empirically medical prescription, individual self-medication or a low adherence to treatment, inefficient hospital infection control services and poor hygiene. In studies performed, among antibiotics increasing resistance against fluoroquinolones has become evident ${ }^{20}$. In urinary system infections, broad-spectrum fluoroquinolones are frequently used. Very frequent and unnecessary usages facilitate development of resistance $^{21}$. In a study performed, E. coli was susceptible to ciprofloxacin and ceftriaxone in $81.8 \%$ and $90.9 \%$ of the cases, respectively. All of these cases were found to be susceptible to imipenem and in $70 \%$ of the cases to trimethoprim-sulfamethoxazole. Clinical features of urinary system infections are similar in diabetic and non-diabetic patients ${ }^{2,22}$. In diabetic patients, antibiotic resistance against ciprofloxacin used in the treatment of urinary system infections is gradually increasing. Ciprofloxacin resistant $E$. coli strains responsible for community-acquired and nosocomial urinary infections were compared in the whole world and higher rates of resistance was detected for $E$. coli strains isolated in nosocomial infections ${ }^{10}$.

Quinolones belong to an important group of antibiotics used in the empirical treatment of UTIs in adults. Widespread and erroneous use of this group of antibiotics facilitates development of resistance against quinolones in E.coli strains and other microorganisms ${ }^{23}$. In Turkey, in patients with UTIs who convey risk factors for the development of antibiotic resistance, including especially ciprofloxacin use, necessity of performing urine cultures and antibiotic susceptibility tests have been indicated20. In studies performed in our country, susceptibility rates for ciprofloxacin have been reported to range between 41.1 and 94.2 percent $^{24}$. In our study, susceptibility rates for ciprofloxacin were found to be 55.2 and
80.8\%, in diabetics and non-diabetics, respectively. Ciprofloxacin-resistant bacterial infections have mainly associated with chromosomal mutations that alter DNA gyrase and topoisomerase IV, upregulation of the expression of native efflux pumps, alteration of the amount or porins types and transference of resistance genes by ${ }^{25,26}$. In our study, we were not able to detect the specific resistance mechanisms.

In various studies performed in our country ampicillin-susceptibility rates of $E$. coli isolates were found to range between 11.9 and 51 percent ${ }^{27}$. Higher resistance rates against ampicillin have significantly restricted its use in UTIs. The lowest susceptibility rates in our study were found for ampicillin both in diabetics and non-diabetics (27.1 and 51.4\%, respectively). Antibiotic-susceptibility rates for ampicillin-sulbactam and amoxicillin-clavulanic acid were 65.6 and $56.2 \%$ in diabetics and 46.4 and $58.8 \%$ in non-diabetics, respectively. Since many alternatives exist for the empirical treatment of UTIs, use of these antimicrobials in UTI is contraindicated ${ }^{24}$.

For a long time, trimethoprimsulfamethoxazole (SXT) has been used in the treatment of community-acquired UTIs. However, with increasing rates of antibioticresistance among $E$. coli strains have restricted its use. In studies performed with E. coli strains causing UTIs, susceptibility rates for SXT has been reported to range between 32.5 and $62.5 \%{ }^{27}$. If rates of antibiotic-resistance against SXT among uropathogens exceed 19-20\%, then use of trimethoprim-sulfamethoxazole in the empirical treatment of UTIs is not recommended $^{28}$. In our study, susceptibility rates of SXT were 64.5 and $64.7 \%$ in diabetics and non-diabetics, respectively.

One of the frequently used antimicrobials in the treatment of urinary system infections is second- and third-generation oral cephalosporins. In patients complaining of 
fever and vomiting frequently intramuscular form of ceftriaxone has been preferred. Studies performed in our country, susceptibility rates for ceftriaxone have been reported to vary between 57.1 and 93 percent $^{24}$. However in our study susceptibility rates for ceftriaxone were found to be 39.6 and $66.1 \%$ in diabetics and non-diabetics, respectively. In recent years, increase in the antibiotic-resistance rates may be related to ESBL production in Gram-negative rods especially and predominantly in E. coli and Klebsiella spp. Since limited the number of reports on the use of cephalosporins in Enterobacteriaceae infections are available, before their use in the treatment of UTIs, should be definitely evaluated based on bacterial identification and antibiotic susceptibility test results ${ }^{24}$.

Antibiotic resistance rates of Escherichia coli against aminoglycosides are relatively lower. Since they can be administered only through parenteral route and because of their serious side effects, they are employed in limited number of indications ${ }^{23}$. In our study, susceptibility rates for gentamycin were $88.8 \%$ and $89.7 \%$ in diabetics and non-diabetics, respectively.

Nitrofurantoin is an antibacterial agent specific to urinary tract infections. It is a cheap medication in Turkey. A clinically significant resistance against nitrofurantoin has not been observed. As a justification of this lack of clinically significant resistance, its effect on various regions of bacteria has been indicated. It is effective on many strains of Escherichia coli and enterococci ${ }^{24}$. In studies performed in our country susceptibility rates for nitrofurantoin were found to range between 64.7 and $97.1 \%$ among E. coli isolates ${ }^{19,24}$. In our study, antibiotic susceptibility rates for nitrofurantoin were detected as 96.8 and $100 \%$ in diabetics and non-diabetics, respectively. Since in many studies performed recently higher antibiotic susceptibility rates for nitrofurantoin have been reported, this drug can be preferred as a first-line alternative in the treatment of simple cystitis especially on an outpatient basis.

In a study by Vinken et al., the authors detected similar rates of resistance of $E$. coli isolates in blood and urine cultures of diabetic and nondiabetic patients against ampicillin, trimethoprim-sulfamethoxazole, ciprofloxacin and nitrofurantoin ${ }^{29}$. Accordingly, we concluded that diabetes per se does not affect sensitivity of antibiotics against uropathogens. However, the previous study 30 in Gondar reported a significant correlation between hyperglycemia, and UTI. This indicates instantaneous determination of fasting blood glucose level may not be associated with bacteriuria. In a study performed by Wang et al. excepting increased antibiotic resistance against second- and third-generation cephalosporins, the authors observed similar antibiotic resistance profiles in diabetic and non-diabetic patients 4 . In our study, in the diabetic group microorganisms mostly demonstrated the highest rates of resistance against ampicillin, cephalosporins, ciprofloxacin, and amoxicillin-clavulanic acid and in the non-diabetic group against ampicillin, amoxicillin-clavulanic acid, cefuroxime, and trimethoprimsulfamethoxazole. We detected similar antibiotic resistance profiles in both groups, while in the diabetic group significantly higher antibiotic resistance was noted against ciprofloxacin in the diabetic group $(\mathrm{p}<0.01)$. Further large scale and glucose level follow-up studies are needed to conclude whether fasting blood glucose level is associated with significant bacteriuria or not.

This study has some limitations which have to be pointed out. The small patient population and the retrospective nature of the study do not allow us to well interpret regarding on clinical complaints, gender, comorbid conditions and asymptomatic bacteriuria treatment options. However, this present work will be the subject of ongoing studies. In the future, we therefore 
think that such studies would be more appropriate in clinically well-defined prospective patient groups by using diagnostic accuracy using laboratory and clinical algorithms. Even with the above-mentioned limitations, this study showed that there was a clear relationship between urinary tract infections and Cipro resistance.

In conclusion, $E$. coli is the most frequent cause of community-acquired infections. We detected significantly higher antibiotic resistance in the diabetic group against ciprofloxacin which is frequently used in our country in the empirical treatment of urinary system infections. Awareness is needed of both the population and health professionals about the importance for the correct use of antibiotics, and it is very important to take into account the result of antibiotics susceptibility tests. As a more correct approach, in the empirical treatment of urinary system infections in diabetic patients, quinolones should not be preferred and treatment planning should be made based on the results of the antibiotic susceptibility test results.

\section{Conflict of interest}

There is no conflict of interest.

Ethical standard Approval was obtained from the Ethics Committee of Firat University (meeting 14, issue, 3, dated 06.09.2018)

Declaration of Conflicting Interests: The authors declare that they have no conflict ofinterest.

Financial Disclosure: No financial support was received.

\section{REFERENCES}

1. International Diabetes Federation. Diabetes Atlas. 6th edition, update 2014. http://www.idf.org/diabetes atlas

2. Simkhada R. Urinary tract infection and antibiotic sensitivity pattern among diabetics. Nepal Med Coll J. 2013; $15: 1-4$.

3. Yu S, Fu AZ, Qiu Y, et al. Disease burden of urinary tract infections among type 2 diabetes mellitus patients in the US. J Diabetes Complications 2014; 28 :621-6.

4. Wang $\mathrm{MC}$, Tseng $\mathrm{CC}, \mathrm{Wu} \mathrm{AB}$, et al. Bacterial characteristics and glycemic control in diabetic patients with Escherichia coli urinary tract infection. J Microbiol Immunol Infect 2013; 46 :24-9.

5. Sewify M, Nair S, Warsame S, et all. Prevalence of Urinary Tract Infection and Antimicrobial Susceptibility among Diabetic Patients with Controlled and Uncontrolled Glycemia in Kuwait. J Diabetes Res. 2016; 6573215.

6. Rawat V, Singhai M, Kumar A, et all. Bacteriological and resistance profile in isolates from diabetic patients. $\mathrm{N}$ Am J Med Sci. 2012; 4 :563-8.

7. Nitzan O, Elias M, Chazan B, et all. Urinary tract infections in patients with type 2 diabetes mellitus: review of prevalence, diagnosis, and management. Diabetes Metab Syndr Obes 2015; 8: 129-36.

8. American Diabetes Association. Standards of medical care in diabetes. Diabetes Care 2015; 38: 1-93.

9. Catry B, Latour $\mathrm{K}$, Bruyndonckx $\mathrm{R}$, et all. Characteristics of the antibiotic regimen that affect antimicrobial resistance in urinary pathogens. Antimicrob Resist Infect Control. 2018; 7: 76.

10. Kahlmeter G, Poulsen HO. Antimicrobial susceptibility of Escherichia coli from communityacquired urinary tract infections in Europe: the ECO.SENS study revisited. Int J Antimicrob Agents 2012; 39: 45-51.

11. Tsakiridou E, Makris D, Chatzipantazi V, et all. Diabetes and hemoglobin a1c as risk factors for nosocomial infections in critically ill patients. Crit Care Res Pract. 2013: 279479.

12. Aswani SM, Chandrashekar UK, Shivashankara KN et all. Clinical profile of urinary tract infections in diabetics and non-diabetics. Australasian Medical Journal 2014; 7: 29-34.

13. Fünfstück R, Nicolle LE, Hanefeld M, et all. Urinary tract infection in patients with diabetes mellitus. Clin Nephrol 2012; 77 :40-8. 
14. Geerlings S, Fonseca V, Castro-Diaz D, et all. Genital and urinary tract infections in diabetes: impact of pharmacologically-induced glucosuria. Diabetes Res Clin Pract. 2014; 103 :373-81.

15. Hirji I, Guo Z, Anderrson S.W, et all. Incidence of urinary tract infection among patients with type 2 diabetes in the UK General Practice Research Database 2012; 26: 513-6.

16. Hammar N, Farahmand B, Gran M, et all. Incidence of urinary tract infection in patients with type 2 diabetes. Experience from adverse event reporting in clinical trials. Pharmacoepidemiol Drug Saf 2010; 19: 1287-92.

17. Akhtar MS, Mohsin N, Zahak A, et all. Antimicrobial sensitivity pattern of bacterial pathogens in urinary tract infections in South Delhi, India. Rev Recent Clin Trials. 2014; $9: 271-5$.

18. Choe HS, Lee SJ, Cho YH, et all.; GPIU Asian Investigators. Aspects of urinary tract infections and antimicrobial resistance in hospitalized urology patients in Asia: 10-Year results of the Global Prevalence Study of Infections in Urology (GPIU). J Infect Chemother 2018; 24 :278-83.

19. Naz H, Cevik FC, Aykın N. Hastane kökenli üriner sistem infeksiyonları ve antibiyotik direnç profili. Dicle Med J 2009; 36: 85-90.

20. Fasugba O, Gardner A, Mitchell BG, et all. Ciprofloxacin resistance in community-and hospitalacquired Escherichia coli urinary tract infections: a systematic review and meta-analtsis of observational studies.BMC Infectious Diseases 2015; 15: 545-60.

21. Frei CR, Labreche MJ, Attridge RT. Fluoroguinolones in community-acguired pneumonia: guide to selection and appropiate use. Drugs 2011; 71: 757-70.

22. Cıkman A, Gundem NS, Gulhan B, et all. İdrar kültürlerinden soyutlanan Enterobacteriaceae türlerinin GSBL üretimi ile ertapenem ve diğer antibiyotiklere direncinin belirlenmesi. Dicle Med J. 2014; $41: 474-8$.
23. Ijaz M, Khan SM, Hassan M, Bangash IH. Urinary tract infection in diabetic patients; causative bacteria and antibiotic sensitivity J. Med. Sci. 2014; 22 :110-4.

24. Erden S, Çalangu S. Poliklinik hastalarında üriner sistem infeksiyonlarından izole edilen Escherichia coli suşlarının çeşitli antibiyotiklere in vitro duyarlılıkları. İstanbul Tıp Fakültesi Mecmuası 2002; 65: 147-9.

25. Redgrave LS, Sutton SB, Webber MA, Piddock LJ. Fluoroquinolone resistance: mechanisms, impact on bacteria, and role inevolutionary success. Trends Microbiol. 2014; 22 :438-45.

26. Kim ES, Hooper DC.Clinical importance and epidemiology of quinolone resistance. Infect Chemother. 2014; 46: 641-6.

27. Aral M, Kireçci E, Doğan SŞ. İdrar örneklerinden izole edilen gram negatif bakteriler ve antibiyotiklere direnç oranlarının retrospektif olarak değerlendirilmesi. Türk Mikrobiyoloji Cemiyeti Derg 2011; 41: 139-42.

28. Gangcuangco LM, Alejandria M, Henson KE, et all. Prevalence and risk factors for trimethoprimsulfamethoxazole-resistant Escherichia coli among women with acute uncomplicated urinary tract infection in a developing country. Int J Infect Dis 2015; 34: 55-60.

29. Vinken JEM, Mol HE, Verheij TJM, et all. Antimicrobial resistance in women with urinary tract infection in primary care: No relation with type 2 diabetes mellitus. Prim Care Diabetes. 2018; $12: 80-6$.

30. Yismaw G, Asrat D, Woldemanuel Y, et all. Urinary tract infection: Bacterial etiologies, drug resistance profile and associated risk factors in diabetic patients attending Gondar University Hospital, Gondar, Ethiopia. European Journal of Experimental Biology 2012; 2: 889-98. 